increased litter weight at birth (e.g. for twins; $6 \cdot 6,8 \cdot 2,7 \cdot 9$ and $8.6 \mathrm{~kg}$; residual s.d. 1.38) and greater gains by lambs reared as pairs when the ewes were fed on a common diet $(242,264,268$ and $278 \mathrm{~g}$ /day; residual s.d. $42 \cdot 9$ ).

77. THE EFFECT OF A DIETARY SUPPLEMENT OF PROTECTED FAT ON THE YIELD AND COMPOSITION OF MILK FROM EWES RECEIVING DIFFERENT LEVELS OF FISH MEAL IN THEIR DIET

M. Kovessy, J. J. Robinson, A. K. Lough and R. P. Aitken, Rowett Research Institute, Bucksburn, Aberdeen AB2 9SB.

Eighteen individually penned Finn Dorest ewes each suckling two lambs by Suffolk rams were given daily $2.5 \mathrm{~kg}$ of a complete diet consisting of milled hay, barley and fish meal and containing $9 \mathrm{MJ}$ metabolizable energy per $\mathrm{kg}$. Three intakes of fish meal were imposed at random (six ewes per treatment) and were $36(\mathrm{~L}), 108(\mathrm{M})$ or $180(\mathrm{H}) \mathrm{g} /$ day. Within each level of intake ewes received for 10-day periods (three periods in all) either a lipid supplement $(t)$ of $200 \mathrm{~g} / \mathrm{day}$ calcium palmitate (Megalac, Volac Ltd) protected from hydrolysis in the rumen or no supplement $(-)$. Within each level of intake of fish meal half the ewes received the treatment sequence +-+ and the other half -+- over the three periods. Daily intakes of crude protein were 246 (L), 300 (M) and $353(\mathrm{H}) \mathrm{g}$. Milk yields, measured by the oxytocin technique on the last 3 days of each period, were not altered by fat supplementation at any of the three levels of intake of fish meal, the overall mean daily yield being $2.5 \mathrm{~kg}$. In contrast the inclusion of dietary fat increased $(P<0.001)$ the fat concentration of the milk by $15 \cdot 8,18 \cdot 8$ and 12.8 (s.e.d $1.45) \mathrm{g} / \mathrm{kg}$ on L, M and $\mathrm{H}$ treatments respectively. There were corresponding small decreases in milk protein of $1 \cdot 0(\mathrm{~L}), 2 \cdot 0$ $(\mathrm{M})$ and $1.1(\mathrm{H})$ (s.e.d. 0.48$) \mathrm{g} / \mathrm{kg}$. In a second experiment the fat concentration of milk from ewes (no. =6) receiving $300 \mathrm{~g} /$ day of the protected lipid was 111 (s.e. 5.9 ) g/kg compared with 89 (s.e. $5 \cdot 1$ ) $\mathrm{g} / \mathrm{kg}$ for controls (no. $=6$ ). Corresponding values for the proportion of total $\mathrm{C}_{16}$ fatty acids in the milk were 0.38 and 0.25 (s.e.d. $0.019, P<0.001$ ) and for total $\mathrm{C}_{4}$ to $\mathrm{C}_{14}$ fatty acids, $0 \cdot 24$ and $0 \cdot 36$ (s.e.d. $0 \cdot 020$, $P<0.001)$. These results show that the protected lipid enhances the fat content of milk and alters its fatty acid composition. The effects appear to be independent of dietary protein intake.

78. The rôle OF MAgnesium in the Aetiology OF UROLITHIASIS IN FATTENING STORE LAMBS AND INTENSIVELY-REARED LAMBS

A. Harker, BOCM Silcock, Wright Street, Renfrew PA4 9 AH and D. Cuddeford, Royal (Dick) School of Veterinary Studies, Department of Veterinary Clinical Studies, Veterinary Field Station, Easter Bush, Roslin EH25 9RG.

High density levels of magnesium ( $>2 \mathrm{~g} / \mathrm{kg}$ dry matter (DM)) have been implicated as the main causal factor of urinary calculi in concentrate-fed lambs. Experiments were performed to try to reproduce this effect of high magnesium (from added calcined magnesite) on the incidence of urolithiasis in lambs. (a) Store lambs : $\operatorname{diets}$ A, B and C contained magnesium in the following concentrations, A $2.9 ; \mathrm{B} 8.6 ; \mathrm{C} 2.9 \mathrm{~g} / \mathrm{kg}$ DM. Twenty-four Blackface lambs were each allocated to $A$ and $B$ and the control group of 160 lambs was fed $C$ and hay $a d$ libitum. The animals were housed and fed ad libitum until they were killed at an average live weight of $35 \mathrm{~kg}$. No animals showed clinical signs of urolithiasis and at post mortem only a trace of calculous material was recovered from one lamb fed $\operatorname{diet}$ A. (b) Intensive lamb : housed Suffolk and Suffolk cross lambs were fed a starter beginning at 3 to 4 weeks of age and changed to a finisher at a live weight of $23 \mathrm{~kg}$. The food was either high magnesium starter (5.7) and finisher (6.0) or low magnesium starter (2.3) and finisher $(2.8 \mathrm{~g} / \mathrm{kg} \mathrm{DM})$. Twentytwo single lambs and 32 twins were assigned to both high and low magnesium diets. Lambs fed additional magnesium drank more water per kg DM intake and one of the single lambs showed clinical signs of urolithiasis and was killed. No others showed clinical signs and from the 62 killed there was no post-mortem recovery of calculous material. It is clear from the results obtained that magnesium per se is not the cause of urolithiasis in lambs.

\section{ENERGY AND NITROGEN RETENTION IN MILK-FED LAMBS}

A. R. Mantecón and R. Peláez, Departamento de Producción Animal Universidad de León, León 24007, España and F. J. Overjero, C.S.I.C., Apdo 788, León 24080, España.

The effect of the level of energy intake (EI), crude protein concentration of the diet (CP), age and sex of growing lambs upon the retention of energy (ER) and nitrogen (NR) was studied. Milk diets based on cow's milk supplemented with either calcium caseinate or glucose and fat-filled skim milk were fed to 114 lambs of the Churra breed in a $3 \times 3 \times 2 \times 2$ factorial experiment using the comparative slaughter technique. The EI were $0.63,1.05$ and $1.46 \mathrm{MJ}$ gross energy per $\mathrm{kg} \mathrm{M}^{(1) 75}$ per day. The CP were 179,240 and $349 \mathrm{~g} / \mathrm{kg}$ dry matter. Males and females between 2 and 16 , and 16 and 30 days of age were used. The live-weight gain (LWG) and its energy and nitrogen concentration were significantly influenced by the four factors studied and only the nitrogen content of the gain was independent of the sex of the lambs. The daily ER (MJ/day) and NR (g/day) were estimated from the LWG (kg/day) and the live weight ( $\mathrm{LW}, \mathrm{kg}$ ) of the lambs according to the equations:

$$
\begin{gathered}
\mathrm{ER}=-0 \cdot 17+15 \cdot 19 \mathrm{LWG}-16 \cdot 32 \mathrm{LWG} / \mathrm{LW} \\
-279 \cdot 57(\mathrm{LWG} / \mathrm{LW})^{2} ; \\
R=0.965 ; \text { residual s.d. }=0 \cdot 24 \\
\mathrm{NR}=0.38+31 \cdot 42 \mathrm{LWG}-72 \cdot 12 \mathrm{LWG} / \mathrm{LW} \\
+559 \cdot 70(\mathrm{LWG} / \mathrm{LW})^{2} ; \\
R=0.966 ; \text { residual s.d. }=0.52
\end{gathered}
$$

Since the EI and the CP influence the ER and the NR it is impossible to estimate the $\mathrm{ER}\left(\mathrm{MJ} / \mathrm{kgM}^{0.75}\right.$ per day) and the $\mathrm{NR}\left(\mathrm{g} / \mathrm{kg} \mathrm{M}^{0.75}\right.$ per day) from the intake of the metabolizable energy (MEI, MJ/kg $\mathrm{M}^{0.75}$ per day) and nitrogen (NI, g/kg $\mathrm{M}^{0.75}$ per day) according to the equations:

$$
\begin{gathered}
\mathrm{ER}=-0.28+0.04 \mathrm{NI}+0.53 \mathrm{MEI} ; \\
R=0.938 ; \text { residual s.d. }=0.07 \\
\mathrm{NR}=-0.35+0.23 \mathrm{NI}+0.79 \mathrm{MEI} ; \\
R=0.896 ; \text { residual s.d. }=0.11
\end{gathered}
$$


Combining the four equations it is possible to calculate the optimum energy/protein relationship of the diet. The values decrease with increasing LWG and ranged from 130 to 71 and from 155 to $126 \mathrm{~kJ}$ ME per g CP for the lambs of 2 to 16 and 16 to 30 days of age respectively.

\section{Supplementation of SILAGE FOR Finishing LAMBS}

C. M. Minter and W. M. Tempest, Harper Adams Agricultural College, Edgmond, Nr. Newport, Shropshire TF10 $8 N B$.

Two trials were conducted to investigate the effect of type of energy source and protein level on the performance of lambs weaned at 8 weeks, at mean live weight $18 \mathrm{~kg}$, and fed on silage. In trial 1, 59 lambs were allocated within sex and breed at random to one of three types of energy supplement: commercial lamb creep pellets (CR), whole barley (BA), dried molassed sugar-beet pulp (BP). BA and BP were balanced with fish meal to give the same dietary crude protein concentration as CR (195 g/kg dry matter (DM)) in which the protein source was also based on fish meal. In trial 2, 39 lambs were allocated within sex and breed at random to one of two supplementary protein levels: no supplementary protein (OP), supplementary protein in the form of fish meal $(+P)$, both groups being fed the same energy supplement as BP. In both trials silage was offered ad libitum and supplements at $300 \mathrm{~g}$ /day fresh weight. Group mean silage DM intakes, and lamb performance was recorded. Silage analysis was year 1: $270 \mathrm{~g} \mathrm{DM}$ per $\mathrm{kg}, 670 \mathrm{~g}$ digestible organic matter per $\mathrm{kg} \mathrm{DM}$, $10 \cdot 6 \mathrm{MJ}$ metabolizable energy (ME) per $\mathrm{kg} \mathrm{DM}, 210 \mathrm{~g}$ crude protein (CP) per kg DM, pH 5.9; year 2: $223 \mathrm{~g} \mathrm{DM}$ per $\mathrm{kg}$, $630 \mathrm{~g}$ digestible organic matter per $\mathrm{kg} \mathrm{DM}, 10 \cdot() \mathrm{MJ}$ ME per $\mathrm{kg} \mathrm{DM}, 149 \mathrm{~g} \mathrm{CP}$ per $\mathrm{kg} \mathrm{DM}, \mathrm{pH} \mathrm{4 \cdot 2.} \mathrm{Lamb} \mathrm{growth} \mathrm{rates}$ (g/day) were in trial 1: CR 126, BA $108, \mathrm{BP} 148$ (s.e. 4-47, $P<0.01$ ) and in trial 2: OP 103, +P 130 (s.e. $4.90, P<0.01$ ) Silage DM intakes (kg/day) were in trial 1: CR $0.54, \mathrm{BA} 0.46$, $\mathrm{BP} 0.51$; and in trial 2: OP $0.28 ;+\mathrm{P} 0.30$. In trial 1, half of the lambs on $\mathrm{BA}$ failed to finish due to liver damage which may have arisen by lactic acidosis. The results support the hypothesis that silage is best supplemented with a digestible fibre energy source and high-quality protein.

\section{SAFE GRAZING For WeANEd LamBS}

M. S. Griffiths and C. James, Trawsgoed Experimental Husbandry Farm, Aberystwyth, Dyfed SY23 4HT

Nematode parasites of the alimentary tract are an important cause of poor performance in lambs and young cattle. The provision of 'clean' pasture for sheep would virtually eliminate the need for regular anthelmintic treatment and would support higher levels of lamb performance than a contaminated pasture. Unfortunately, a clean grazing system is difficult to establish and maintain on an upland farm. Two 2.8-ha paddocks of a predominantly perennial ryegrass sward were managed during the spring and summer of 1985 to produce two different levels of pasture nematode infestation for weaned lamb grazing during the autumn of that year. Both areas were grazed by non-lactating mature ewes until 5
February 1985. The 'safe' area (S) was then closed for two silage cuts and grazed for 11 days during early August by replacement dairy heifers. The contaminated area (C) was set stocked with 21 cross-bred ewes and their May-born Suffolk cross lambs per ha between 29 April and 28 August. Dung samples were collected from lambs grazing $C$ at 8,12 and 16 weeks of age. Herbage and dung samples were collected from $\mathrm{S}$ and $\mathrm{C}$ at weaning (28 August) and 14-day intervals until lambs were removed from trial on 31 October. One hundred and thirty-eight lambs were divided into two groups by weight and condition at weaning and set stocked at 25 per ha on $S$ and $\mathrm{C}$ following an anthelmintic treatment. Lambs were selected for slaughter to produce carcasses of Meat and Livestock Commission fat class 2 or 3 . Eight hundred and twenty-five $\mathrm{kg}$ of finished lamb was sold from paddock $\mathrm{S}$ and $640 \mathrm{~kg}$ from paddock $\mathrm{C}$. Faecal egg counts increased on $\mathrm{C}$ during October to 1300 eggs per gram and remained at insignificant levels on $S(57$ to 46$)$ over the trial period. Safe grazing would appear to be an alternative for upland farms.

82. GROWTH RATE AND CARCASS COMPOSITION OF BORDER LEICESTER $\times$ SCOTTISH BLACKFACE (BLB), EAST FRIESLAND $\times$ BLACKFACE $($ EFB) AND EAST FRIESLAND $\times$ NORTH COUNTRY CHEVIOT (EFC) LAMBS

J. M. Doney, A. D. M. Smith and D. A. Sim, Hill Farming Research Organisation, Bush Estate, Penicuik, Midlothian EH26 OPY.

Crossing of hill ewes by East Friesland rams gives good reproductive and lactation performance but little is known of growth and development of wether lambs. Castrated male BLB (Greyface) lambs (no. = 26), EFB (no. = 32) and EFC $($ no. $=22)$ were individually penned and offered a concentrate diet (12.5 MJ metabolizable energy per $\mathrm{kg}, 183 \mathrm{~g}$ crude protein per $\mathrm{kg}$ dry matter) ad libitum after weaning (live weight 24 to $31 \mathrm{~kg}$ ). They were killed at fixed weight intervals from $32 \mathrm{~kg}$ (initial) to 'maturity' (15 months). Mature live weights were 91 (s.e. 5.4), 84 (s.e. 3.1 ) and 81 (s.e. 3.7) kg, respectively. Mean daily live-weights gains ( $g /$ day) between from 32 to $44 \mathrm{~kg}$ live weight were 281 (s.e. $21 \cdot 8$ ), 251 (s.e. 12.2) and $199($ s.e. 16.8) $(P<0.01)$ and mean food intake $(\mathrm{kg} /$ day) was 1.64 (s.e. 0.053$), 1.56$ (s.e. 0.034$)$ and 1.42 (s.e. $0.043)(P<0.05)$. At maturity, dissectable fat tissue was about 0.5 carcass weight in all groups. In the live-weight range 32 to $44 \mathrm{~kg}$ regression coefficients on carcass weight of subcutaneous fat, total carcass fat and muscle, respectively, were 0.351 (s.e. 0.0429 ), 0.569 (s.e. 0.0474 ), 0.351 (s.e. 0.0381 ) for BLB; 0.282 (s.e. $0 \cdot 0258), 0 \cdot 563$ (s.e. 0.0527$), 0.381$ (s.e. ().0519) for EFB and 0.239 (s.e. 0.0213 ), 0.486 (s.e. 0.0506 ) and 0.485 (s.e. 0.0415$)$ for EFC. Calculated carcass weights $(\mathrm{kg})$ and corresponding live weights for carcasses containing $130 \mathrm{~g}$ subcutaneous fat per $\mathrm{kg}$ carcass weight were $17 \cdot 5(39), 20 \cdot 1(42)$ and $22 \cdot 4(46)$. At these weights total carcass fat was $300 \mathrm{~g} / \mathrm{kg}$ carcass weight in all groups. Muscle weights were $9 \cdot 2,10 \cdot 7$ and $12.5 \mathrm{~kg}$. To achieve such carcass weights the groups would have required 25,39 and 75 days and 41,61 and $107 \mathrm{~kg}$ food respectively. BLB and EFB did not differ significantly but EFC had lower mature weight, grew more slowly and required proportionately more food to reach a higher carcass weight at similar carcass composition. 